\title{
ANALISIS PENGGUNAAN INFORMASI AKUNTANSI DAN INFORMASI NON AKUNTANSI DALAM KEPUTUSAN PEMBERIAN FASILITAS KREDIT PADA PT. BANK MANDIRI (PERSERO) TbK AREA MANADO
}

\author{
Marshella Patricia Niode, David Paul Elia Saerang, Ventje Ilat \\ (Email : tricella_mn@yahoo.com)
}

\begin{abstract}
One of the efforts that the bank made to anticipate and minimize the credit risk is already started since the applicant proposed the loan. This thing is done by analyze all sort of the information from the applicant. Loan giver must do a deep analyze to sorts of information due to the giving of the right decision of loan, and by that for, to analyze the loan proposal of the applicant, the bank needs the accounting information in the form of financial statement or in the other form along with non-accounting information from the applicant that's both historical as well as contemporary, or future. The purpose of this study was to analyze the use of accounting information in the decision to grant credit facilities and to analyze the use of non-accounting information in the decision to grant credit facilities. The object of this research is PT. Bank Mandiri (Persero) Tbk Area Manado. The instrument in this research is questionares and interview. Analysis method that used is the deskriptive analysis. The result of the research is that the accounting information and non-accounting information is needed to determine the distribution of loan properly given to debitor in the concerned to reduced the non performing loan (NPL) in the PT. Bank Mandiri (Persero) Tbk. Keywords: Accounting Information, Non-Accounting Information, Decision of Loan Facilities.
\end{abstract}

\section{PENDAHULUAN}

Kegiatan perekonomian di Indonesia didukung dengan adanya kegiatan perbankan. Banyak dari para debitur memanfaatkan perbankan untuk menambah modal usahanya supaya usahanya berkembang dan maju. Terdapat banyak bank di Indonesia yang bisa dipilih debitur untuk menambah modal usahanya. Keberadaan Bank di suatu daerah akan memberikan dampak positif membantu perkembangan ekonomi suatu daerah. Apabila keberadaan bank secara merata ada di setiap daerah dan terintegrasi dengan baik, maka akan mempunyai dampak pada perkembangan positif ekonomi suatu negara. Bank merupakan bisnis kepercayaan yang bergerak di sektor usaha jasa keuangan, sarat dengan peraturan dan ketentuan yang dikeluarkan oleh otoritas moneter. Tujuan dikeluarkannya peraturan dan ketentuan tersebut yaitu untuk mengatur sistem operasional perbankan sehingga dana masyarakat yang dikelola akan menghasilkan keuntungan bagi kedua belah pihak.

Bisnis dari perbankan ini di antaranya adalah menghimpun dana dari masyarakat berupa tabungan, deposito dan giro kemudian disalurkan kembali kepada masyarakat dalam bentuk kredit yang merupakan fungsi intermediasi bank, dengan demikian bisa dikatakan bahwasanya bank adalah tempat yang mempertemukan pihak yang minus dana dan pihak yang memiliki dana, artinya pihak yang memiliki dana ini akan menempatkan dananya di bank sedangkan pihak yang membutuhkan dana di bank dapat memohonkan kreditnya di bank tersebut, sesuai dengan UU No. 19 tahun 1998 pasal 1, huruf 2 menyebutkan bahwa bank adalah suatu bentuk badan usaha yang menghimpun dana dari masyarakat dalam bentuk simpanan dan menyalurkannya kembali dalam bentuk kredit dan atau bentuk-bentuk lainnya dalam rangka meningkatkan taraf hidup rakyat banyak.

Sampai sekarang terutama di negara-negara yang sedang berkembang, penyaluran dana bank yang terbesar adalah melalui kredit. Hal ini terjadi karena volume permintaan dana (kredit) jauh lebih besar dari volume penawaran dana masyarakat (simpanan). Data Bank 
Indonesia tahun 2014 mencantumkan bahwa jumlah volume permintaan kredit pada industri perbankan dari tahun 2011 hingga akhir tahun 2013 terus mengalami peningkatan. Hal ini bisa dilihat dari Tabel 1 seperti di bawah ini.

Tabel 1. Perkembangan Baki Debet (Sisa Pokok Pinjaman) Kredit UMKM menurut Klasifikasi Usaha

\begin{tabular}{lccc}
\hline \multicolumn{1}{c}{ Baki Debet } & $\mathbf{2 0 1 3}$ & $\mathbf{2 0 1 4}$ & $\mathbf{2 0 1 5}$ \\
\hline Kredit Usaha Mikro & $137,797.7$ & $179,748.3$ & $199,123.4$ \\
Kredit Usaha Kecil & $193,060.3$ & $224,348,3$ & $239,194.5$ \\
Kredit Usaha Menengah & $308,613.5$ & $363,481.1$ & $392,338.3$ \\
\hline \multicolumn{1}{c}{ Total } & $\mathbf{6 3 9 , 4 7 1 . 5}$ & $\mathbf{7 6 7 , 5 7 7 . 6}$ & $\mathbf{8 3 0 , 6 5 6 . 2}$ \\
\hline
\end{tabular}

Sumber : Bank Indonesia (2016)

Peningkatan ini tercermin pula pada pendapatan bunga yang berasal dari penyaluran kredit yang merupakan komponen yang dominan dibandingkan pendapatan yang berasal dari kegiatan-kegiatan atau jasa-jasa bank yang lainnya sehingga kredit merupakan sumber penghasilan yang menentukan kelangsungan hidup suatu bank, bahkan dapat dikatakan kredit adalah jantung bagi bank. Setiap usaha selalu dihadapkan pada risiko, demikian pula dengan penyaluran kredit yang dilakukan oleh bank, yaitu risiko apakah dana dan bunga dari kredit yang dipinjamkan akan dapat kembali sesuai dengan akad yang dibuat oleh pihak bank maupun debitur atau calon nasabah. Berdasarkan ketentuan perbankan seperti dikutip dalam Simanjuntak (1999), tidak terbayarnya sebagian atau seluruh bunga dan atau pokok pinjaman, mewajibkan bank menggolongkan kredit tersebut sebagai kredit yang tidak sehat atau kredit bermasalah atau dikenal sebagai Non Performing Loan (NPL) dan dikolektibilitaskan sesuai keadaan masing-masing: Kredit Lancar, Kredit Kurang Lancar, Kredit Dalam Perhatian khusus, Kredit Diragukan, dan Kredit Macet, selanjutnya bank wajib mencadangkan sejumlah dana Pembentukan Penyisihan Penghapusan Aktiva Produktif (PPPAP) untuk menutupi kerugian akibat kredit bermasalah tersebut. Penyisihan dana akan mengurangi laba bank, sehingga semakin besar kredit bermasalah atau yang berpotensi untuk bermasalah akan sangat membebani atau bahkan menghancurkan bank yang bersangkutan.

Kredit bermasalah sama sekali tidak bisa ditiadakan. Hal yang dapat dilakukan oleh bank adalah meminimalkan risiko dengan cara melakukan evaluasi atau analisis kredit, baik sejak awal pemberian kredit maupun ketika kredit sudah berjalan. Salah satu upaya yang dilakukan bank untuk mengantisipasi atau untuk meminimalisir risiko kredit dimulai sejak nasabah mengajukan permohonan kredit, yaitu pada tahap awal pengambilan keputusan pemberian kredit. Hal ini dilakukan dengan cara menganalisa berbagai informasi yang diperoleh dari calon debitur sesuai dengan prispip 5C (Character, Capacity, Capital, Colatteral, Condition of Economy) yang pada dasarnya dapat dikelompokkan kedalam dua jenis informasi yaitu informasi kuantitatif dan informasi kualitatif pada saat calon debitur mengajukan permohonan kredit kepada pihak bank.

Informasi kuantitatif atau yang disebut informasi akuntansi adalah informasi yang bersifat keuangan seperti laporan keuangan, kapasitas produksi dan lain-lain, yang selanjutnya disebut sebagai informasi akuntansi. Kreditur atau pihak bank menggunakan informasi akuntansi dari calon debitur untuk pengambilan keputusan kredit, sedangkan untuk investor digunakan untuk keputusan investasi. Bagi kreditur, informasi akuntansi merupakan dasar untuk memprediksi prospek usaha dan kemampuan perusahaan dalam menghasilkan aliran kas dimasa yang akan datang, yang akan digunakan sebagai pedoman antara lain untuk menentukan kebijakan pemberian kredit. Bagi investor, informasi akuntansi merupakan titik awal untuk memprediksi prospek aliran kas. Informasi akuntansi di dalamnya terdapat beberapa indikator di antaranya profit margin, Return of Investment (ROI), Return of Equity 
(ROE), Return of Assets (ROA), Debt Service Ratio (DSR), dan Cash Flow. Sedangkan informasi kualitatif atau informasi non akuntansi adalah informasi yang bersifat non keuangan, seperti karakter dari calon debitur, histori pinjaman dari calon nasabah, jenis agunan dari calon debitur, lokasi usaha, lokasi agunan, jenis usaha calon debitur, legalitas usaha calon debitur dan informasi lain yang relevan dalam rangka keputusan pengambilan kredit bagi calon debitur. Pemberi kredit harus melakukan analisis mendalam terhadap berbagai informasi dari calon debitur, dalam rangka pengambilan keputusan kredit yang tepat, sehingga untuk menganalisa permohonan kredit calon debitur, bank memerlukan informasi akuntansi baik yang berupa laporan keuangan formal (financial statement), maupun dalam bentuk lain serta informasi bukan akuntansi dari calon debitur baik yang bersifat masa lalu (historis), masa sekarang (contemporary), atau masa depan (future). Tujuan analisis adalah memberikan gambaran yang selengkap mungkin dan dapat dipertanggungjawabkan mengenai kondisi keuangan maupun kondisi bukan keuangan calon debitur. Keputusan pemberian kredit ini dilihat dari apakah permohonan kredit tersebut bisa direkomendasikan atau tidak oleh pihak yang berwenang dalam memutus kredit.

Alasan peneliti menggunakan Bank Mandiri sebagai sampel dalam penelitian ini adalah karena Bank Mandiri merupakan salah satu bank pemerintah di Indonesia dengan asset terbesar dan tergolong dalam bank sehat. Sebagai bank yang baru berkecimpung di dunia perkreditan, Bank Mandiri sudah dapat dikatakan sebagai bank yang cukup berkembang dan menjadi saingan yang berat bagi bank-bank besar lainnya. Bank Mandiri juga memiliki laba terbanyak kedua setelah Bank BRI sehingga lebih menambah ketertarikan peneliti untuk melakukan penelitian di bank tersebut. Berdasarkan pengamatan terhadap Annual Report PT. Bank Mandiri (Persero) Tbk tahun 2016, perkembangan Non Performing Loan (NPL) Bank Mandiri mengalami peningkatan dari tahun 2013 sampai dengan tahun 2015. Perkembangan Non Performing Loan (NPL) dari tahun 2013 sampai dengan 2015 yaitu tahun 2013 sebesar $0.37 \%$ meningkat pada tahun 2014 menjadi $0.44 \%$ dan bertambah pada tahun 2015 menjadi $0.60 \%$, hal ini menyebabkan perusahaan harus menyisihkan laba yang diperolehnya untuk pembentukan CKPN (Cadangan Kerugian Penurunan Nilai) yang berimbas pada kerugian perusahaan dikarenakan laba yang diperolehnya berkurang. Untuk mengurangi peningkatan Non Performing Loan (NPL), maka perusahaan perlu untuk lebih memperhatikan penyaluran kreditnya dengan meminimalisir resiko yang ada.

\section{TINJAUAN PUSTAKA}

\section{Teori Keputusan}

Menurut Ralp C. Davis menyatakan bahwa Keputusan ialah suatu hasil pemecahan masalah yang dihadapinya dengan tegas. Suatu keputusan adalah suatu jawaban yang pasti terhadap suatu pertanyaan. Keputusan harus menjawab sebuah pertanyaan tentang apa yang dibicarakan dalam hubungannya dengan suatu perencanaan. Keputusan bisa pula berupa suatu tindakan terhadap pelaksanaan yang sangat menyimpang dari rencana semula.

\section{Informasi}

Menurut Kamus Besar Bahasa Indonesia, informasi diartikan sebagai penerangan; pemberitahuan; kabar atau berita tentang sesuatu. Informasi merupakan keseluruhan makna yang menunjang amanat yang terlihat dibagian-bagian amanat itu.

\section{Akuntansi}

Definisi yang dapat dipakai untuk memahami akuntansi dijelaskan dalam buku $A$ Statement of Basic Accounting Theory (ASOBAT) dalam Harahap (2007), dijelaskan bahwa akuntansi adalah proses mengidentifikasikan, mengukur, dan menyampaikan informasi 
ekonomi sebagai bahan informasi dalam hal mempertimbangkan berbagai alternatif dalam mengambil kesimpulan oleh para pemakainya.

\section{Informasi Akuntansi}

Belkaoui (2000) mendefinisikan informasi akuntansi sebagai informasi kuantitatif tentang entitas ekonomi yang bermanfaat untuk pengambilan keputusan ekonomi dalam menentukan pilihan-pilihan diantara alternatif-alternatif tindakan. Penggunaan informasi akuntansi itu untuk perencanaan strategis, pengawasan manajemen dan pengawasan operasional (Anthony, 1965; Simons, 1991).

\section{Pengertian Informasi Non Akuntansi}

Selain informasi akuntansi yang mempengaruhi keputusan pemberian fasilitas kredit modal kerja kepada calon debitur, informasi non akuntansi juga dapat mempengaruhi jadi tidaknya pemberian fasilitas kredit modal kerja kepada calon debitur. Informasi non akuntansi menurut Mintarti (1994) dalam Hasibuan (2003), meliputi :

1) Jaminan kredit

2) Reputasi karakter debitur

3) Pendidikan manajemen

4) Pengalaman manajemen

5) Diversifikasi usaha

6) Sektor ekonomi yang dibiayai

\section{Penelitian Terdahulu}

Hasibuan (2003) meneliti tentang pengaruh informasi akuntansi dan non akuntansi terhadap keputusan pemberian kredit modal kerja pada Bank Bumiputera cabang Medan. Data diperoleh dengan mendatangi kantor bank Bumiputera Cabang Medan, dan dilakukan dengan metode survei dengan memberikan pertanyaan kepada pejabat bank yang berkompeten untuk diisi. Hasil penelitian menunjukkan bahwa informasi akuntansi dan non akuntansi secara bersama-sama tidak berpengaruh terhadap keputusan pemberian kredit modal kerja, sedangkan secara parsial, informasi akuntansi yang berpengaruh terhadap kolektabilitas kredit modal kerja adalah likuiditas, struktur modal, dan skala usaha, sedangkan yang tidak berpengaruh adalah kelayakan usaha, perputaran piutang, dan perputaran persediaan. Informasi non akuntansi yang tidak berpengaruh terhadap kolektabilitas kredit modal kerja adalah jaminan kredit, reputasi bisnis, diversifikasi usaha dan sektor ekonomi yang dibiayai, dan yang berpengaruh adalah pengalaman debitur. Sudaryono (2005), meneliti tentang persepsi analis kredit tentang informasi akuntansi dan non akuntansi pengaruhnya terhadap keputusan kredit. Data diperoleh dengan metode survey. Hasil penelitian menunjukkan bahwa untuk BNI informasi akuntansi lebih berpengaruh dibandingkan dengan informasi non akuntansi, tetapi untuk Bank Mandiri informasi non akuntansi lebih berpengaruh terhadap keputusan kredit daripada informasi akuntansi.

\section{KERANGKA KONSEPTUAL}

\section{Kerangka Konseptual Penelitian}

Kerangka pemikiran teoritis yang menunjukkan hubungan antar variabel berdasarkan telaah pustaka dapat diilustrasikan sebagai berikut : 


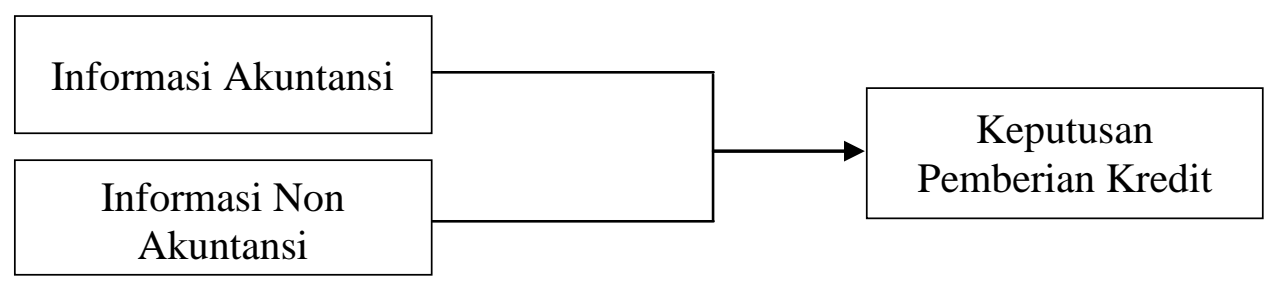

Gambar 1. Kerangka Pemikiran

\section{Model Analisis}

Dalam penelitian ini pendekatan yang dilakukan adalah melalui pendekatan kualitatif. Maksudnya data yang akan dikumpulkan adalah dari hasil observasi/pengamatan lapangan, wawancara, serta data-data pendukung lainnya. Tujuan dari penelitian ini adalah untuk mengetahui hubungan informasi akuntansi dan informasi non akuntansi dalam pengambilan keputusan pemberian fasilitas kredit.

\section{METODE PENELITIAN}

\section{Pendekatan Penelitian}

Penelitian ini menggunakan penelitian pendekatan kualitatif deskriptif. Menurut Sugiyono (2012) penelitian kualitatif adalah metode penelitian yang digunakan untuk menyelidiki pada kondisi obyek yang alamiah, dimana peneliti adalah sebagai instrumen kunci, teknik pengumpulan data dilakukan secara trianggulasi (gabungan), analisis data bersifat induktif, dan hasil penelitian kualitatif lebih menekankan makna daripada generalisasi. Penelitian ini menggunakan metode kualitatif deskriptif karena permasalahan yang akan diteliti merupakan proses suatu langkah kerja yang kompleks dan penuh makna. Pendekatan kualitatif dipandang sesuai untuk penelitian ini karena untuk memperoleh gambaran mengenai prinsip-prinsip umum atau pola-pola yang berlaku umum dengan kenyataan yang terjadi dalam lokasi penelitian.

\section{Teknik Pengumpulan Data}

Dalam penelitian ini, teknik pengumpulan data dilakukan dengan :

1. Wawancara/Kuesioner

Pada tahap ini peneliti melakukan tanya jawab secara langsung kepada para informan penelitian yaitu para analis kredit dan pemutus kredit yang telah bekerja di atas 1 tahun. Wawancara dilakukan dengan melontarkan pertanyaan secara langsung dan juga membagikan angket/kuesioner kepada para analis dan pemutus kredit. Jumlah informan yang akan diwawancara adalah 50 (lima puluh) orang sesuai dengan tugas pokok dan fungsi dari masing-masing informan yang berkaitan dengan topik penelitian.

2. Observasi

Menurut Burhan Bungin (2011) Observasi adalah kemampuan seseorang untuk menggunakan pengamatannya melalui hasil kerja panca indra mata serta dibantu dengan panca indra lainnya. Sehingga dapat disimpulkan bahwa metode observasi adalah metode pengumpulan data yang digunakan untuk menghimpun data penelitian melalui pengamatan dan pengindraan. Pada tahap ini peneliti melakukan pengamatan langsung terhadap objek yang akan diteliti.

3. Studi Pustaka

Pada tahap studi pustaka ini, peneliti mempelajari jurnal-jurnal penelitian terdahulu, buku, artikel serta berbagai sumber yang berhubungan dengan 
penelitian yang akan diteliti dengan tujuan untuk lebih memperdalam pengetahuan dan daya paham atas objek penelitian.

\section{ANALISIS DAN PEMBAHASAN HASIL PENELITIAN}

\section{Hasil Penelitian}

Jenis kredit yang diambil dalam penelitian ini adalah jenis kredit mikro yang fasilitas pembiayaannya diberikan kepada semua usaha mikro dan usaha rumah tangga baik berbentuk perusahaan, kelompok usaha dan perorangan (seperti pedagang, petani, peternak dan nelayan). Kredit Mikro yang diberikan oleh Bank Mandiri meliputi Kredit Usaha Mikro (KUM) dan Kredit Serbaguna Mikro (KSM). Kredit Usaha Mikro (KUM) yang diberikan berupa Kredit Investasi (KI) dan Kredit Modal Kerja (KMK) untuk pengembangan usaha produktif skala mikro. Kredit Usaha Mikro adalah kredit yang diberikan kepada pengusaha mikro untuk membiayai kebutuhan usaha produktif baik untuk kebutuhan investasi maupun kebutuhan modal kerja. Kredit Usaha Mikro (KUM) khusus diberikan kepada Usaha Mikro dengan maksimum limit kredit sebsesar Rp 100 juta dan khusus untuk fasilitas top up diperkenankan sampai dengan limit Rp 200 juta.

Kredit Serbaguna Mikro (KSM) adalah kredit yang diberikan kepada pegawai yang memiliki penghasilan tetap atau profesi tetap, pensiunan atau kepada target market tertentu untuk membiayai berbagai macam kebutuhannya. Untuk suku bunga kredit yang diberikan Bank Mandiri khususnya kredit mikro memiliki standar suku bunga berbeda antara Kredit Usaha Mikro dan Kredit Serbaguna Mikro. Suku bunga standar yang diberikan untuk kredit Usaha Mikro diberikan Maksimal 2\% dan dapat berubah sesuai keputusan pemegang kewenangan, sedangkan Kredit Sebaguna Mikro yang biasa diberikan untuk pegawai diberikan suku bunga maksimal $1.5 \%$ untuk pegawai yang statusnya masih kontrak dan $0.975 \%$ untuk pegawai yang statusnya sudah merupakan pegawai tetap.

Tabel 2 Tabel Perkembangan Aset Produktif dan NPL Bank Mandiri

\begin{tabular}{lccc}
\hline \multicolumn{1}{c}{ Uraian } & $\mathbf{2 0 1 3}$ & $\mathbf{2 0 1 4}$ & $\mathbf{2 0 1 5}$ \\
\hline Aset Produktif & & & \\
Aset Produktif \& Non Produktif bermasalah terhadap total & $1.17 \%$ & $1.15 \%$ & $1.56 \%$ \\
aset produktif dan aset non produktif & & & \\
Aset produktif bermasalah terhadap total aset produktif & $1.43 \%$ & $1.42 \%$ & $1.96 \%$ \\
CKPN aset keuangan terhadap aset produktif & $2.86 \%$ & $2.61 \%$ & $3.10 \%$ \\
Kredit Bermasalah (NPL Bruto) & $1.60 \%$ & $1.66 \%$ & $2.29 \%$ \\
NPL Netto & $0.37 \%$ & $0.44 \%$ & $0.60 \%$ \\
\hline
\end{tabular}

Sumber : Annual Report PT. Bank Mandiri (Persero) Tbk tahun 2016

Berdasarkan tabel 5.4 di atas terlihat perkembangan Non performing loan (NPL) Bank Mandiri dari tahun 2013 sebesar $0.37 \%$, 2014 sebesar $0.44 \%$ dan 2015 sebesar $0.60 \%$ mengalami kenaikkan. Hal ini menunjukkan bahwa Bank Mandiri harus lebih memperhatikan Non performing loan. Kenaikkan ini mengindikasikan bahwa para pemberi kredit belum terlalu memperhatikan syarat kredit yang diberikan kepada nasabah dalam hal ini informasi akuntansi dan non akuntansi. Dalam upaya menjaga dan meningkatkan kualitas kredit mikro, menurunkan portofolio Non Performing Loan (NPL) dan melakukan penghematan CKPN, Bank Mandiri membuat sebuah program yaitu Rezeki Lunas NPL khusus di bulan Desember 2015. Pesertanya adalah Mikro Kredit Sales (MKS) dengan skema program yaitu jika MKS bisa membantu penagihan untuk pelunasan debitur di kolektibilitas 3, 4 dan 5 maka akan diberikan insentif khusus.

Visi Micro Banking sebagai bagian dari Retail Strategy Corporate Plan Bank Mandiri untuk menjadi bank pesaing utama untuk segmen pembiayaan mikro di Indonesia dengan 
Strategi Utama "the Strongest Challenger in Micro Banking". Beberapa inisiatif strategis yang akan dilaksanakan oleh Micro Banking adalah :

1. Pembukaan 436 jaringan MMU yang terdiri dari 100 cabang MMU, 300 Unit MMU dan 36 Cluster di tahun 2016 yang berpotensi mengdongkrak ekspansi kredit segmen mikro dan dana TabunganMU.

2. Perekrutan 17.715 Agent Branchless Banking untuk mendukung dan meningkatkan financial inclusion dan dana tabungan.

3. Implementasi RTTA dengan menggunakan WEB base sampai ke level Cluster untuk dapat meningkatkan kinerja baik kredit maupun tabungan dan juga dapat meminimalisir risiko-risiko yang akan timbul.

4. Optimalisasi KUM Transaksional untuk dapat mendukung kinerja portofolio kredit mikro melalui value-chain dari nasabah segmen Corporate Banking maupun Commercial Banking.

5. Penggunaan teknologi finger print sebagai alat untuk meningkatkan keamanan dalam proses pemberian kredit segmen mikro.

6. Menyalurkan Kredit Usaha Rakyat (KUR) dalam rangka mendukung program pemerintah Republik Indonesia.

2. Pembahasan

1. Peran Informasi Akuntansi dalam pengambilan keputusan pemberian kredit pada PT. Bank Mandiri (Persero) Tbk.

Berdasarkan penelitian sebelumnya yang dilakukan oleh Hasibuan (2003), informasi akuntansi yang berpengaruh terhadap tingkat kolektibilitas kredit modal kerja adalah likuiditas, struktur modal dan skala usaha, sedangkan yang tidak berpengaruh adalah kelayakan usaha, perputaran piutang dan perputaran persediaan. Perbedaan penelitian ini dengan penelitian yang dilakukan sebelumnya adalah pada penelitian ini hasilnya informasi akuntansi berpengaruh terhadap pengambilan keputusan kredit.

2. Peran Informasi Non Akuntansi dalam pengambilan keputusan pemberian kredit pada PT. Bank Mandiri (Persero) Tbk.

Berdasarkan penelitian sebelumnya yang dilakukan oleh Septriawan (2011), informasi non akuntansi tidak terlalu berpengaruh terhadap keputusan kredit. Perbedaan penelitian ini dengan penelitian yang dilakukan sebelumnya adalah pada penelitian ini hasilnya informasi non akuntansi berpengaruh terhadap pengambilan keputusan kredit.

\section{KESIMPULAN}

Dari hasil penelitian dan pembahasan maka dapat disimpulkan beberapa kesimpulan sebagai berikut.

1. Informasi Akuntansi berupa Pertumbuhan Penjualan, Profit margin, Modal sendiri, Kemampuan Membayar, Modal Usaha, Perputaran Persediaan, cash flow memiliki peran dalam pengambilan keputusan pemberian kredit pada PT. Bank Mandiri (Persero) Tbk karena Informasi Akuntansi dibutuhkan oleh pihak kreditur untuk penilaian. Informasi Akuntansi untuk pihak luar menyajikan suatu gambaran menyeluruh tentang kondisi keuangan dan hasil usaha suatu organisasi. Indikator-indikator informasi akuntansi tersebut dibutuhkan oleh pihak kreditur untuk memutuskan apakah kredit kepada debitur akan diberikan atau tidak.

2. Informasi non Akuntansi berupa Karakter calon debitur, laporan BI Checking, jenis agunan, lokasi usaha, lokasi agunan, jenis usaha, legalitas usaha juga memiliki peran dalam pengambilan keputusan pemberian kredit pada PT. Bank Mandiri (Persero) Tbk. 
Indikator-indikator ini menjadi penilaian tambahan bagi kreditur untuk memperkuat keputusan mereka atas kredit yang diberikan kepada debitur.

\section{DAFTAR PUSTAKA}

Aan Komariah dan Djam'an Satori. 2013. Metodologi Penelitian Kualitatif. Penerbit : Alfabeta. Bandung.

Agusthia, Hervika. 2012. Analisis Pengaruh Informasi Akuntansi dan Informasi Non Akuntansi terhadap Keputusan Kredit. Accounting Analysis Journal 1. Semarang.

Anthony, A.N. and Reece, J.S. 1989. Accounting : Text and Cases. 8th Ed. Illinois.

Arikunto, Suharsimi. 2013. Prosedur Penelitian : Suatu Pendekatan Praktik. Rineka Cipta. Jakarta.

Bank Indonesia dan Biro Riset Infobank. Statistik Ekonomi Keuangan Indonesia. Vol. XXXII Nomor 01 Januari 2014.

Belkaoui, Ahmed Riahi. 2000. Teori Akuntansi. Edisi Pertama. Alih Bahasa Marwata S.E., Akt. Salemba Empat. Jakarta.

Bungin, Burhan. 2011. Penelitian Kualitatif. Penerbit : Kencana Predana Media Group. Jakarta.

Davis, C. Ralph. 1951. The Fundamentals of Top Management. Harper \& Brother. NewYork.

Dwi, Martani., dkk. 2012. Akuntansi Keuangan Menengah Berbasis PSAK. Buku 1. Penerbit : Salemba Empat. Jakarta.

Fitriyah, Hadiah. 2006. Analisis Faktor-faktor yang Mempengaruhi Penggunaan Informasi Akuntansi Pada Usaha Menengah Kabupaten Sidoarjo. Program Pascasarjana Universitas Airlangga. Surabaya.

Hansen dan Mowen. 2005. Akuntansi Manajemen. Edisi 7. Salemba Empat. Jakarta.

Harahap, Sofyan Syafri. 2007. Teori Akuntansi. Raja Grafindo Persada, Jakarta.

Hasan, I. 2002. Pokok-pokok Materi Teori Pengambilan Keputusan. Ghalia Indonesia. Jakarta.

Hasibuan. 2003. Pengaruh Informasi Akuntansi terhadap Keputusan Pemberian Fasilitas Modal Kerja pada Bank Bumiputera Cabang Medan. Program Pascasarjana Universitas Sumatera Utara. Medan.

Holmes, S., and D. Nicholls. 1988. An Analysis of The Use of Accounting Information by Australian Small Business. Journal of Small Business Management.

Ikatan Akuntansi Indonesia. 2001. Standar Profesional Akuntan Publik. Penerbit Salemba Empat. Jakarta.

Ikatan Akuntansi Indonesia. 2015. Pernyataan Standar Akuntansi Keuangan.

Kasmir. 2012. Dasar-dasar Perbankan. Ed. Revisi. Cet 11. Jakarta: Rajawali Pers.

Lisdiani, Fenny. 2013. Analisis Informasi Akuntansi dan Non Akuntansi Dalam Pengambilan Keputusan Kredit Modal Kerja pada PT. Bank Central Asia Tbk Cabang Bengkulu. Skripsi. Jurusan Akuntansi Fakultas Ekonomi dan Bisnis. Bengkulu.

Mintarti, Sri. 1994. Pengaruh Informasi Askuntansi dalam Pengambilan Keputusan Kredit pada Perbankan di Propinsi Kalimantan Timur. Thesis S2. Fakultas Pasca Sarjana, Universitas Gajah Mada. Yogyakarta.

Mulyadi. 1995. Auditing. Edisi kelima, Buku Dua. Penerbit Salemba Empat. Jakarta.

Priyatno, Dwi. 2008. Mandiri Belajar SPSS. Mediakom: Yogyakarta.

Sarjono Haryadi, dan Julianita Winda. 2011. SPSS vs LISREL. Penerbit Salemba Empat: Jakarta.

Sarwono, Jonathan. (2012). Path Analysis. Elex Media Komputindo : Jakarta.

Sekaran, Uma. 2003. Research Method for Business A Skill Building Approach. John Wiley and Sons, Inc. 4th edition. New York. 
Septriawan, Mohammad R. 2010. Pengaruh Informasi Akuntansi dan Informasi Non Akuntansi terhadap Pengambilan Keputusan Kredit pada PT. Bank CIMB Niaga Tbk Cabang Medan Petisah. Tesis S2. Sekolah Pascasarjana Universitas Sumatera Utara. Medan.

Siagian, P. Sondang. 2003. Organisasi, Kepemimpinan, dan Perilaku Administrasi. Gunung Agung. Jakarta.

Simanjuntak, A. Tiurma. 1999. Analisis Kebutuhan Informasi Akuntansi dan Informasi Bukan Akuntansi Dalam Pengambilan Keputusan Kredit. Program Studi Magister Manajemen Universitas Diponegoro. Semarang.

Stoner, A. F. Stoner. 2003. Manajemen Keputusan. Penerbit : Rineka Cipta. Jakarta.

Sudaryono. 2005. Persepsi Analisi Kredit Tentang Informasi Akuntansi dan informasi Non

Akuntansi Pengaruhnya terhadap Keputusan Kredit. Program Studi Magister Sains

Akuntansi Universitas Diponegoro. Semarang.

Sugiyono. 2007. "Metode Penelitian Kuantitatif Kualitatif dan R\&D". Bandung: Alfabeta

Sugiyono. 2009. Metode Penelitian Bisnis (Pendekatan Kuantitatif, Kualitatif, dan R\&D).

Penerbit Alfabeta. Bandung.

Sugiyono. 2012. Memahami Penelitian Kualitatif. Penerbit Alfabeta. Bandung.

Sugiyono. 2013. Metode Penelitian Pendidikan. Penerbit Alfabeta. Bandung.

Takoudjou, N.A., D.W. Leopold., and S.K. Boniface. 2013. The Implications of the Accounting Data Management on the Exercise of Loans Discretion by Banks in Cameron: The Case of Small and Medium Size Enterprises. African Journal of Social Sciences. (Vol. 3). No. 3: 18-28.

Terry, R. George. 1968. Principle of Management. Universitas Michigan. Michigan.

Williams, Chuck. 2001. Manajemen. Penerbit : Salemba Empat. Jakarta

http://media.corporateir.net/media_files/IROL/14/146157/Annual_Report_Mandiri_Gabung_ FinaL.pdf

www.bankmandiri.co.id

www.bi.go.id/id/umkm/kredit/data/Documents/Perkembangan Kredit UMKM dan MKM JAN 2016_BD.pdf 